\title{
Update of a study of crude oil production workers 1946-94
}

\author{
Barbara J Divine, Christine M Hartman
}

\begin{abstract}
Objective-To update information on workers in the petroleum industry engaged in the production of crude oil to determine whether the patterns of mortality have changed with 14 additional years of follow up.

Methods-All workers were employed at company production and pipeline locations sometime during 1946-94. The cohort now consists of 24124 employees with an average of 22 years of follow up.

Results-The overall mortality, and most cause specific mortalities were lower than or similar to those for the general United States population. For white men $(81 \%$ of the cohort), there were 4361 observed deaths and 5945 expected, resulting in a significantly lower standardised mortality ratio (SMR) of 73 . There were significant deficits for all the leading causes of death in the United States including all cancers, cancer of the lung, stroke, heart disease, respiratory disease, and accidents. Slightly increased mortality was found for cancer of the prostate, cancer of the brain and central nervous system, and cancer of other lymphatic tissue. For benign and unspecified neoplasms, the SMR was 152 (95\% confidence interval $(95 \%$ CI) 95 to 230). There was a significant increase for acute myelogenous leukaemia that was restricted to people who were first employed before 1940 and who were employed in production and pipeline jobs for $>30$ years. Overall mortality patterns for non-white men and women were similar to those for white men. Mortality patterns for white men were also examined by duration of employment, time first employed, and by job group.

Conclusions-The results of the updated study showed a favourable mortality experience for crude oil production workers compared with the United States population.

(Occup Environ Med 2000;57:411-417)
\end{abstract}

Keywords: petroleum industry; occupational cancer; mortality; crude oil

Texaco, PO Box 1404, Houston, TX 77251, USA

B J Divine

C M Hartman

Correspondence to: Dr B Devine

divinbj@texaco.com

Accepted 18 January 2000 whose primary exposure was to crude oil. 'The report documented the known hazards associated with exposure to crude oil and employ- examined the patterns of mortality in refinery workers and petroleum distribution workers, only one epidemiological study has been carried out on production and pipeline workers ment in production. The cohort comprised more than 11000 United States workers whose mortality experience was recorded from 1946-80. There were significant deficits in mortality from all causes of death combined, all malignant neoplasms, stroke, arteriosclerotic heart disease, respiratory disease, accidents, and lung cancer. Two causes of death had standardised mortality ratios (SMR) >100, thyroid cancer and benign and unspecified neoplasms; neither SMR was significant.

In this report, the period of observation was extended to the end of 1994, for a maximum follow up of 49 years. These additional 14 years of follow up allowed updated comparisons of additional causes and rates of death among crude oil production workers with those in the general United States population. The objective was to determine whether employment in production and pipeline operations with its potential exposure to crude oil and other possibly hazardous materials has had an effect on the mortality experience of these workers.

\section{Materials and methods}

Members of the original study cohort worked at production or pipeline facilities for at least 1 day between 1 January 1946 and 31 December 1980, were employed at one of these facilities for at least 6 months, and were employed by a participating facility either on their last day of employment or on the original study end date (31 December 1980). The study data collection and vital status follow up methods are detailed in Divine and Barron. ${ }^{1}$

The current cohort consists of the members of the original cohort plus people who met the same eligibility criteria by 31 December 1994. New members of the cohort who had ever worked at the participating locations were identified with information from the company's computerised personnel system. The work histories for employed members of the original cohort were updated until 31 December 1994 with the computerised personnel system. Information on new cohort members was obtained primarily from the computerised personnel system and from original records if early work history information had not been computerised. Members whose records lacked information on sex or race were assumed for the analysis to be men and white.

Each employee's complete work history was coded. When more than one job was held concurrently, all were coded with the same start and end dates, and the time was divided evenly among the jobs during analysis. Because of the many different jobs, jobs with similar 
Table 1 Mortality study of crude oil workers: total cohort by vital status

\begin{tabular}{|c|c|c|c|c|c|c|c|c|c|c|}
\hline \multirow{2}{*}{$\begin{array}{l}\text { Vital status at } \\
\text { the end of } 1994\end{array}$} & \multicolumn{2}{|c|}{ White men } & \multicolumn{2}{|c|}{ Non-white men } & \multicolumn{2}{|c|}{ White women } & \multicolumn{2}{|c|}{ Non-white women } & \multicolumn{2}{|l|}{ Total } \\
\hline & $n$ & $\%$ & $n$ & $\%$ & $n$ & $\%$ & $n$ & $\%$ & $n$ & $\%$ \\
\hline Alive & 14520 & 74.1 & 1098 & 91.7 & 2453 & 81.5 & 305 & 92.4 & 18376 & 76.2 \\
\hline Dead & 4361 & 22.3 & 53 & 4.4 & 195 & 6.5 & 3 & 0.9 & 4612 & 19.1 \\
\hline Unknown & 707 & 3.6 & 47 & 3.9 & 361 & 12.0 & 21 & 6.7 & 1136 & 4.7 \\
\hline Total & 19588 & 100 & 1198 & 100 & 3009 & 100 & 326 & 100 & 24124 & 100 \\
\hline
\end{tabular}

responsibilities and potential exposures were grouped into larger categories chosen by a company industrial hygienist most familiar with producing and pipeline operations. These groups account for almost all of the jobs and are the same as those developed and used in the earlier report. ${ }^{1}$

The vital status of the cohort was updated to 31 December 1994 from company files when available, and otherwise from the National Death Index (NDI), the Social Security Administration Master Beneficiary Record file, or the Health Care Financing Administration (HCFA). People who were known to be alive in 1979 were assumed to be alive if no death record was found in the NDI to the end of 1994. Copies of the death certificates for deceased employees were obtained from company files when available or from the health departments in the states where the deaths occurred. A trained nosologist coded causes of death listed on the death certificates to the eighth revision of the International Classification of Diseases (ICD-8).

The last date of observation for a cohort member was defined as the date last employed if lost to follow up, the date of death if known, the date of the NDI search if known to be alive in 1979 or later, the date of the HCFA search if
HCFA indicated the person was still alive, the date of the personnel system search for people still receiving pension payments, or the current study end date (31 December 1994) for those known to be alive as of 1 January 1995.

Patterns of mortality were analysed with the computer program developed by Monson. ${ }^{2}$

The program uses the observed and expected numbers of deaths for specific causes to calculate SMRs with the United States population as the comparison group and 95\% confidence intervals (95\% CIs) assuming a Poisson distribution for the observed frequency in the numerator of the SMR. Person-years of observation were counted from the date the employee accumulated 6 months of employment or the study start date, whichever came last, until the date last observed.

Total mortality was examined by race and sex. Because of the few non-white women ( $1.4 \%$ of the total cohort), patterns of mortality for all women were examined with the United States mortalities for white women as the comparison. Also, for white men, patterns of mortality were examined by duration of employment, by time first employed, and by job group. The small numbers in the other race-sex groups preclude making similar subgroup analyses.

Table 2 Study of crude oil workers: SMRs for selected causes of death, by sex and race, 1946-94

\begin{tabular}{|c|c|c|c|c|c|c|c|c|c|}
\hline \multirow[b]{2}{*}{ Cause of death (ICDA-8) } & \multicolumn{3}{|c|}{ White men $n=19588 p-y=434397$} & \multicolumn{3}{|c|}{ Non-white men $n=1198, p-y=17413$} & \multicolumn{3}{|c|}{ All women $n=3338, p-y=51763$} \\
\hline & $\begin{array}{l}\text { Observed } \\
\text { deaths }\end{array}$ & $S M R$ & $95 \% C I$ & $\begin{array}{l}\text { Observed } \\
\text { deaths }\end{array}$ & $S M R$ & $95 \% C I$ & $\begin{array}{l}\text { Observed } \\
\text { deaths }\end{array}$ & $S M R$ & $95 \% C I$ \\
\hline All causes & 4361 & 73 & 71 to 76 & 53 & 46 & 35 to 61 & 198 & 89 & 77 to 102 \\
\hline All cancers $(140-209)$ & 1080 & 83 & 78 to 88 & 15 & 83 & 47 to 138 & 74 & 103 & 81 to 129 \\
\hline Digestive system $(150-159)$ & 252 & 73 & 64 to 83 & 2 & 40 & 5 to 145 & 19 & 130 & 78 to 202 \\
\hline Oesophagus $(150)$ & 18 & 59 & 35 to 93 & 0 & 0 & 0 to 319 & 0 & 0 & 0 to 649 \\
\hline Stomach (151) & 37 & 66 & 47 to 91 & 1 & 115 & 2 to 641 & 2 & 129 & 14 to 464 \\
\hline Large intestine (153) & 95 & 77 & 62 to 94 & 0 & 0 & 0 to 319 & 13 & 197 & 105 to 337 \\
\hline Liver $(155-156)$ & 22 & 94 & 59 to 142 & 0 & 0 & 0 to 691 & 0 & 0 & 0 to 304 \\
\hline Pancreas (157) & 62 & 94 & 72 to 120 & 0 & 0 & 0 to 471 & 4 & 133 & 36 to 341 \\
\hline Larynx (161) & 6 & 35 & 13 to 77 & 0 & 0 & 0 to 945 & 1 & 437 & 6 to 2430 \\
\hline Lung (162) & 347 & 80 & 72 to 89 & 8 & 132 & 57 to 259 & 12 & 93 & 48 to 162 \\
\hline Skin $(172-173)$ & 22 & 86 & 54 to 131 & 0 & 0 & 0 to 1733 & 1 & 79 & 1 to 439 \\
\hline Breast (174) & & & & & & & 15 & 90 & 50 to 149 \\
\hline Cervix (180) & & & & & & & 4 & 157 & 42 to 402 \\
\hline Uterus (181) & & & & & & & 2 & 109 & 12 to 92 \\
\hline Prostate $(185)$ & 135 & 119 & 100 to 141 & 1 & 131 & 2 to 731 & & & \\
\hline Bladder (188) & 30 & 78 & 52 to 111 & 1 & 669 & 9 to 3723 & 0 & 0 & 0 to 575 \\
\hline Kidney (189) & 16 & 51 & 29 to 82 & 1 & 279 & 4 to 1553 & 2 & 178 & 20 to 643 \\
\hline Brain and CNS (191-192) & 37 & 110 & 77 to 152 & 0 & 0 & 0 to 1025 & 2 & 98 & 11 to 352 \\
\hline Thyroid (193) & 4 & 175 & 47 to 449 & 0 & 0 & 0 to 15268 & 0 & 0 & 0 to 2004 \\
\hline Lymphatic and haematopoietic $(200-209)$ & 116 & 93 & 77 to 112 & 1 & 60 & 1 to 332 & 3 & 48 & 10 to 140 \\
\hline Lymphosarcoma and reticulosarcoma (200) & 10 & 56 & 27 to 104 & 0 & 0 & 0 to 2580 & 0 & 0 & 0 to 471 \\
\hline Hodgkin's disease (201) & 5 & 50 & 16 to 118 & 0 & 0 & 0 to 2369 & 1 & 201 & 3 to 1120 \\
\hline Leukaemia (204-207) & 49 & 97 & 72 to 129 & 0 & 0 & 0 to 575 & 0 & 0 & 0 to 154 \\
\hline Other lymphatic tissue $(202,203,208)$ & 45 & 103 & 75 to 138 & 1 & 138 & 2 to 770 & 2 & 81 & 9 to 291 \\
\hline Benign neoplasms $(210-239)$ & 22 & 152 & 95 to 230 & 0 & 0 & 0 to 1655 & 1 & 101 & 1 to 564 \\
\hline Diabetes mellitus (250) & 36 & 41 & 29 to 57 & 0 & 0 & 0 to 201 & 2 & 38 & 4 to 138 \\
\hline Arteriosclerotic heart disease $(410-413)$ & 1489 & 74 & 70 to 77 & 6 & 40 & 15 to 88 & 35 & 72 & 50 to 100 \\
\hline Vascular lesions of CNS $(430-438)$ & 282 & 74 & 66 to 84 & 3 & 59 & 12 to 173 & 14 & 88 & 48 to 147 \\
\hline Non-malignant respiratory disease $(460-519)$ & 299 & 68 & 60 to 76 & 2 & 38 & 4 to 137 & 8 & 59 & 25 to 116 \\
\hline Pneumonia $(480-486)$ & 100 & 63 & 51 to 77 & 0 & 0 & 0 to 129 & 3 & 59 & 12 to 173 \\
\hline Cirrhosis of liver (571) & 38 & 32 & 23 to 44 & 1 & 20 & 0 to 113 & 4 & 84 & 23 to 215 \\
\hline All external causes $(800-998)$ & 283 & 59 & 53 to 67 & 15 & 49 & 27 to 80 & 23 & 139 & 88 to 209 \\
\hline
\end{tabular}

$\mathrm{p}-\mathrm{y}=$ Person years. 
Table 3 Study of crude oil workers: SMRs for selected causes of death, by duration of employment, 1946-94

\begin{tabular}{|c|c|c|c|c|c|c|c|c|c|c|c|c|}
\hline \multirow[b]{2}{*}{ Cause of death (ICDA-8) } & \multicolumn{3}{|c|}{$\begin{array}{l}\text { White men employed }<5 y \\
(n=5415) p-y=125958\end{array}$} & \multicolumn{3}{|c|}{$\begin{array}{l}\text { White men employed } 5-9 y \\
(n=4217) p-y=99432\end{array}$} & \multicolumn{3}{|c|}{$\begin{array}{l}\text { White men employed } 10-19 y \\
(n=3438) p-y=80978\end{array}$} & \multicolumn{3}{|c|}{$\begin{array}{l}\text { White men employed } \geqslant 20 y \\
(n=6518) p-y=128029\end{array}$} \\
\hline & $\begin{array}{l}\text { Observed } \\
\text { deaths }\end{array}$ & $S M R$ & $95 \% C I$ & $\begin{array}{l}\text { Observed } \\
\text { deaths }\end{array}$ & $S M R$ & $95 \% C I$ & $\begin{array}{l}\text { Observed } \\
\text { deaths }\end{array}$ & d $S M R$ & $95 \% C I$ & $\begin{array}{l}\text { Observed } \\
\text { deaths }\end{array}$ & SMR & $95 \% C I$ \\
\hline All causes & 412 & 71 & 64 to 78 & 304 & 63 & 56 to 71 & 718 & 72 & 66 to 77 & 2927 & 75 & 72 to 78 \\
\hline All cancers $(140-209)$ & 95 & 76 & 61 to 93 & 56 & 54 & 41 to 71 & 175 & 83 & 71 to 97 & 754 & 87 & 81 to 93 \\
\hline Digestive system $(150-159)$ & 27 & 93 & 61 to 135 & 13 & 51 & 27 to 87 & 42 & 74 & 53 to 101 & 170 & 73 & 62 to 85 \\
\hline Oesophagus $(150)$ & 4 & 133 & 35 to 341 & 0 & 0 & 0 to 150 & 1 & 20 & 0 to 113 & 13 & 65 & 34 to 110 \\
\hline Stomach (151) & 3 & 69 & 14 to 203 & 3 & 71 & 14 to 208 & 4 & 39 & 10 to 101 & 27 & 72 & 48 to 105 \\
\hline Large intestine (153) & 7 & 67 & 27 to 140 & 5 & 56 & 18 to 131 & 15 & 79 & 44 to 130 & 68 & 79 & 62 to 100 \\
\hline Pancreas (157) & 5 & 87 & 28 to 204 & 4 & 81 & 21 to 208 & 11 & 102 & 51 to 183 & 42 & 94 & 68 to 127 \\
\hline Larynx (161) & 0 & 0 & 0 to 280 & 0 & 0 & 0 to 286 & 1 & 35 & 0 to 198 & 5 & 44 & 14 to 102 \\
\hline Lung (162) & 29 & 68 & 45 to 98 & 13 & 38 & 20 to 65 & 62 & 91 & 70 to 117 & 243 & 85 & 74 to 96 \\
\hline Skin $(172-173)$ & 5 & 121 & 39 to 284 & 4 & 129 & 34 to 330 & 5 & 104 & 33 to 243 & 8 & 59 & 25 to 117 \\
\hline Prostate (185) & 5 & 87 & 28 to 204 & 3 & 54 & 10 to 159 & 13 & 91 & 48 to 156 & 114 & 129 & 107 to 155 \\
\hline Bladder (188) & 2 & 86 & 9 to 313 & 2 & 95 & 10 to 343 & 1 & 17 & 0 to 99 & 25 & 87 & 56 to 129 \\
\hline Kidney (189) & 1 & 30 & 0 to 168 & 1 & 38 & 0 to 213 & 3 & 55 & 11 to 162 & 11 & 54 & 27 to 97 \\
\hline Brain and CNS (191-192) & 4 & 76 & 20 to 196 & 4 & 100 & 26 to 256 & 10 & 147 & 70 to 270 & 19 & 108 & 65 to 168 \\
\hline Lymphatic and haematopoietic (200-209) & 8 & 54 & 23 to 107 & 10 & 86 & 41 to 159 & 19 & 89 & 53 to 139 & 79 & 102 & 81 to 128 \\
\hline Lymphosarcoma and reticulosarcoma (200) & 2 & 111 & 12 to 401 & 0 & 0 & 0 to 235 & 3 & 83 & 16 to 243 & 5 & 46 & 15 to 107 \\
\hline Hodgkin's disease (201) & 1 & 50 & 0 to 278 & 0 & 0 & 0 to 249 & 0 & 0 & 0 to 159 & 4 & 97 & 26 to 248 \\
\hline Leukaemia (204-207) & 3 & 52 & 10 to 153 & 3 & 66 & 13 to 194 & 8 & 94 & 40 to 185 & 35 & 111 & 77 to 154 \\
\hline Other lymphatic tissue $(202,203,208)$ & 2 & 40 & 4 to 147 & 7 & 184 & 73 to 379 & 5 & 75 & 24 to 176 & 31 & 109 & 74 to 155 \\
\hline Benign neoplasms (210-239) & 2 & 117 & 13 to 424 & 1 & 71 & 0 to 397 & 8 & 296 & 127 to 583 & 11 & 127 & 63 to 227 \\
\hline Diabetes mellitus (250) & 2 & 24 & 2 to 88 & 2 & 28 & 3 to 104 & 5 & 34 & 11 to 81 & 27 & 47 & 31 to 68 \\
\hline Arteriosclerotic heart disease $(410-413)$ & 96 & 68 & 55 to 83 & 103 & 77 & 63 to 93 & 262 & 78 & 69 to 88 & 1028 & 73 & 68 to 77 \\
\hline Vascular lesions of CNS $(430-438)$ & 10 & 49 & 23 to 91 & 10 & 48 & 23 to 88 & 43 & 73 & 53 to 98 & 219 & 78 & 68 to 89 \\
\hline Non-malignant respiratory disease $(460-519)$ & 18 & 61 & 36 to 97 & 21 & 79 & 49 to 121 & 33 & 53 & 36 to 74 & 227 & 70 & 61 to 80 \\
\hline Pneumonia $(480-486)$ & 6 & 59 & 21 to 129 & 2 & 21 & 2 to 78 & 10 & 43 & 20 to 79 & 82 & 70 & 56 to 87 \\
\hline Cirrhosis of liver (571) & 8 & 48 & 20 to 95 & 7 & 51 & 20 to 106 & 6 & 23 & 8 to 50 & 17 & 27 & 16 to 43 \\
\hline All external causes (800-998) & 93 & 71 & 58 to 88 & 35 & 44 & 30 to 61 & 63 & 61 & 47 to 79 & 92 & 56 & 45 to 68 \\
\hline
\end{tabular}

$\mathrm{p}-\mathrm{y}=$ Person years.

The SMRs for white men for mesothelioma, non-Hodgkin's lymphoma, leukaemia by cell type, multiple myeloma, and all brain tumours, which are not available in Monson's program, were calculated in the same manner as in an earlier study of refinery, petrochemical, and research workers using the same mortalities. $^{3}$

\section{Results}

There were 24124 people included in the study cohort (table 1) with 503573 personyears of observation. Eighty six per cent of the cohort members were men, and $94 \%$ of the men were white. Ninety per cent of the women were white. Seventy six per cent of the total cohort were still alive, only $4.7 \%$ were lost to follow up, and death certificates were obtained for all but $1.9 \%$ of the known deaths. Because the cohort overwhelmingly consisted of white men $(81 \%)$, the following descriptive statistics refer only to that group. Twenty two per cent of the cohort was still employed on 31 December 1994, and $36 \%$ were retired $(33.7 \%)$ or on permanent disability $(2.2 \%)$. Thirty three per cent were employed by the company at study locations for $\geqslant 20$ years. Thirty five per cent of the cohort was born before 1930, and more than 23\% was first employed before 1950. Sixty eight per cent of the employees who had died were $\geqslant 65$ years of age at the time of death, and over half the deaths occurred since the previous study end date of 31 December 1980.

Table 2 shows the patterns of mortality by race and sex. For white men, 5945 deaths were expected, and only 4361 were observed giving a significant all causes SMR of 73. There were also significant deficits for all cancers combined (SMR 83), digestive system cancers (SMR 73), lung cancer (SMR 80), arterioscle- rotic heart disease (SMR 74), stroke (SMR 74), non-malignant respiratory disease (SMR 68), and all external causes (SMR 59). For cancer of the prostate, cancer of the brain and central nervous system (CNS), and cancer of other lymphatic tissue, the observed number of deaths was similar to the expected number, but the SMRs were slightly increased, and SMRs $>100$ were also found for benign and unspecified neoplasms (SMR 152) and thyroid cancer (SMR 175).

For non-white men, a total of 114 deaths were expected and 53 were observed (SMR 44). There were deficits for many major causes of death such as all cancers combined (SMR 83), cancer of the digestive system (SMR 40), lymphohaematopoietic cancer (SMR 60), arteriosclerotic heart disease (SMR 40), stroke (SMR 59), non-malignant respiratory disease (SMR 38), and all external causes (SMR 49). There were non-significantly increased SMRs for cancer of the lung (SMR 132) and motor vehicle accidents (SMR 126). For all women, there were 198 deaths and 223 were expected giving a significant deficit for the all causes SMR of 89 . There were deficits in mortality from arteriosclerotic heart disease (SMR 72), vascular lesions of CNS (SMR 88), and respiratory disease (SMR 59). For all cancers combined, the observed and expected numbers of deaths were similar. The SMR for cancer of the colon was significantly increased (SMR 197), and there were non-significantly increased SMRs for cancers of the digestive system (SMR 130), cancer of the pancreas (SMR 133), cancer of the cervix (SMR 157), cancer of the ovary (SMR 179), motor vehicle accidents (SMR 138), and suicide (SMR 206).

All further results apply only to the subcohort of white men. Table 3 shows the patterns of mortality by duration of employment, and 
Table 4 Study of crude oil workers: SMRs for selected causes of death, by time first employed, 1946-94

\begin{tabular}{|c|c|c|c|c|c|c|c|c|c|}
\hline \multirow[b]{2}{*}{ Cause of death (ICD-8) } & \multicolumn{3}{|c|}{$\begin{array}{l}\text { White men first employed }<1940 \\
(n=2162) p-y=74085\end{array}$} & \multicolumn{3}{|c|}{$\begin{array}{l}\text { White men first employed 1940- } \\
(n=2352) p-y=93985\end{array}$} & \multicolumn{3}{|c|}{$\begin{array}{l}\text { White men first employed } \geqslant 1950 \\
(n=15074) p-y=266345\end{array}$} \\
\hline & $\begin{array}{l}\text { Observed } \\
\text { deaths }\end{array}$ & $S M R$ & $95 \% C I$ & $\begin{array}{l}\text { Observed } \\
\text { deaths }\end{array}$ & $S M R$ & $95 \% C I$ & $\begin{array}{l}\text { Observed } \\
\text { deaths }\end{array}$ & $S M R$ & $95 \% C I$ \\
\hline All causes & 1817 & 73 & 70 to 77 & 1345 & 75 & 71 to 80 & 1199 & 71 & 67 to 75 \\
\hline All cancers $(140-209)$ & 407 & 84 & 76 to 92 & 351 & 86 & 77 to 95 & 322 & 79 & 70 to 88 \\
\hline Digestive system $(150-159)$ & 89 & 63 & 50 to 77 & 82 & 77 & 61 to 95 & 81 & 85 & 68 to 106 \\
\hline Oesophagus (150) & 5 & 47 & 15 to 110 & 4 & 42 & 11 to 107 & 9 & 87 & 40 to 166 \\
\hline Stomach $(151)$ & 16 & 62 & 35 to 100 & 11 & 66 & 33 to 117 & 10 & 76 & 36 to 139 \\
\hline Large intestine (153) & 31 & 62 & 42 to 88 & 36 & 92 & 65 to 128 & 28 & 80 & 53 to 116 \\
\hline Pancreas (157) & 23 & 89 & 56 to 134 & 20 & 96 & 59 to 148 & 19 & 98 & 59 to 153 \\
\hline Larynx (161) & 3 & 47 & 9 to 136 & 3 & 55 & 11 to 162 & 0 & 0 & 0 to 71 \\
\hline Lung (162) & 111 & 78 & 64 to 94 & 123 & 88 & 73 to 105 & 113 & 76 & 62 to 91 \\
\hline Skin $(172-173)$ & 3 & 44 & 9 to 129 & 6 & 90 & 33 to 196 & 13 & 108 & 58 to 185 \\
\hline Prostate (185) & 72 & 128 & 100 to 161 & 43 & 119 & 86 to 160 & 20 & 96 & 58 to 148 \\
\hline Bladder (188) & 18 & 96 & 57 to 152 & 6 & 49 & 18 to 108 & 6 & 77 & 28 to 168 \\
\hline Kidney (189) & 4 & 37 & 10 to 94 & 6 & 61 & 22 to 134 & 6 & 55 & 20 to 120 \\
\hline Brain and CNS (191-192) & 12 & 134 & 69 to 235 & 9 & 91 & 42 to 173 & 16 & 108 & 61 to 175 \\
\hline Lymphatic and haematopoietic (200-209) & 48 & 109 & 80 to 145 & 36 & 95 & 67 to 132 & 32 & 75 & 51 to 105 \\
\hline Lymphosarcoma and reticulosarcoma (200) & 4 & 56 & 15 to 143 & 3 & 54 & 11 to 157 & 3 & 60 & 12 to 175 \\
\hline Hodgkin's disease (201) & 2 & 67 & 8 to 243 & 2 & 71 & 8 to 258 & 1 & 24 & 0 to 135 \\
\hline Leukaemia (204-207) & 24 & 126 & 81 to 187 & 13 & 86 & 46 to 148 & 12 & 74 & 38 to 129 \\
\hline Other lymphatic tissue $(202,203,208)$ & 16 & 116 & 66 to 189 & 14 & 105 & 57 to 175 & 15 & 90 & 51 to 149 \\
\hline Benign neoplasms $(210-239)$ & 8 & 144 & 62 to 284 & 6 & 134 & 49 to 291 & 8 & 179 & 77 to 353 \\
\hline Diabetes mellitus (250) & 21 & 59 & 36 to 90 & 10 & 38 & 18 to 70 & 5 & 20 & 6 to 47 \\
\hline Arteriosclerotic heart disease $(410-413)$ & 645 & 70 & 65 to 75 & 499 & 80 & 73 to 87 & 345 & 73 & 65 to 81 \\
\hline Vascular lesions of CNS (430-438) & 162 & 78 & 67 to 91 & 89 & 81 & 65 to 100 & 31 & 50 & 34 to 70 \\
\hline Non-malignant respiratory disease $(460-519)$ & 163 & 80 & 68 to 93 & 83 & 59 & 47 to 74 & 53 & 55 & 41 to 72 \\
\hline Pneumonia $(480-486)$ & 63 & 77 & 59 to 99 & 25 & 53 & 34 to 78 & 12 & 40 & 21 to 70 \\
\hline Cirrhosis of liver (571) & 7 & 21 & 9 to 44 & 10 & 29 & 14 to 53 & 21 & 41 & 25 to 63 \\
\hline All external causes (800-998) & 49 & 46 & 34 to 60 & 64 & 59 & 46 to 76 & 170 & 65 & 56 to 76 \\
\hline
\end{tabular}

$\mathrm{p}-\mathrm{y}=$ Person years.

table 4 shows them by time first employed: before 1940, 1940-1949, and after 1949. The patterns were similar for all of the groups regardless of duration or time of employment with significant deficits for most major causes of death. The SMR for cancer of the prostate for those employed $\geqslant 20$ years was significantly increased (SMR 129) as was the SMR for benign and unspecified neoplasms for those employed 10-20 years (SMR 296). For the groups by time first employed, there were no significant increases; however, mortality from cancer of the prostate and cancer of other lymphatic tissue was increased in the two earliest employment groups, mortality from leukaemia was increased in the earliest employment group, and mortality from benign and unspecified neoplasms was increased in all three groups. Trends by duration of employment and by time first employed were examined. The only significant trends were for external causes of death and for cancers of the digestive system by time first employed. There was no reason to think that these increases with later time of employment are likely to be related to employment.

Tables 5 shows the patterns of cancer mortality for those employed in the largest job groups for at least 5 years. These groups all had patterns of mortality similar to those seen for the overall cohort with deficits for the leading causes of death. For those employed in jobs with little or no potential for exposure such as managers, supervisors, and office workers, there was a significantly increased SMR for cancer of the brain and CNS (SMR 183). This group also showed non-significantly increased SMRs for liver cancer, prostate cancer, cancer of other lymphatic tissue, and benign and unspecified neoplasms. For those employed as pumpers in production, there were increased
SMRs for cancer of the prostate, liver cancer, and benign and unspecified neoplasms. For those employed in maintenance, there were significantly increased SMRs for cancer of the prostate and benign and unspecified neoplasms. There were non-significant increases for leukaemia and cancer of other lymphatic tissue. For roustabouts (semi-skilled oil field labourers), there were increased SMRs for cancer of the prostate, liver cancer, benign and unspecified neoplasms, and cancer of other lymphatic tissue. For people employed in pipeline field jobs, there were non-significantly increased SMRs for cancer of the skin, cancer of the prostate, leukaemia, cancer of other lymphatic tissue, and benign and unspecified neoplasms.

There were only three deaths from mesothelioma in the cohort of white men and 8.2 expected for an SMR of 37. These decedents were first employed before 1 January 1960. Thirteen of the deaths from benign and unspecified brain neoplasms were brain tumours and 8.3 deaths were expected for an SMR of 135 (95\% CI 84 to 207). When these were combined with the deaths from cancer of the brain and CNS, there were 50 observed deaths and 41.8 expected from all brain tumours for an SMR of 119 (95\% CI 88 to 157).

Table 6 shows the results of the analyses of specific lymphohaematopoietic cancers. The number of observed deaths from nonHodgkin's lymphoma (lymphosarcoma, reticulum cell sarcoma, and lymphoma combined) was significantly less than expected with an SMR of 69. There were slightly more deaths from multiple myeloma than expected with an SMR of 122. The SMRs were calculated for the cell type specific leukaemias for categories where at least three deaths occurred. Mortality 
Table 5 Study of crude oil workers: SMRs for selected causes of death, by job, 1946-94

\begin{tabular}{|c|c|c|c|c|c|c|c|c|c|c|c|c|c|c|c|}
\hline \multirow[b]{2}{*}{ Cause of death (ICDA-8) } & \multicolumn{3}{|c|}{$\begin{array}{l}\text { Unexposed category, }>5 y \\
\text { White men }(n=5042) \\
p-y=98931\end{array}$} & \multicolumn{3}{|c|}{$\begin{array}{l}\text { Producing, pumper, }>5 y \\
\text { White men }(n=3456) \\
p-y=79128\end{array}$} & \multicolumn{3}{|c|}{$\begin{array}{l}\text { Craft, maintenance, }>5 y \\
\text { White men }(n=2342) \\
p-y=43798\end{array}$} & \multicolumn{3}{|c|}{$\begin{array}{l}\text { Producing, roustabout, } \\
>5 y \text { White men } \\
(n=3820) p-y=96183\end{array}$} & \multicolumn{3}{|c|}{$\begin{array}{l}\text { Pipeline, field, }>5 y \\
\text { White men }(n=1456) \\
p-y=39478\end{array}$} \\
\hline & $\begin{array}{l}\text { Observed } \\
\text { deaths }\end{array}$ & $d S M R$ & $95 \% C I$ & $\begin{array}{l}\text { Observed } \\
\text { deaths }\end{array}$ & $d S M R$ & $95 \% C I$ & $\begin{array}{l}\text { Observed } \\
\text { deaths }\end{array}$ & $d$ SMR & $95 \% C I$ & $\begin{array}{l}\text { Observe } \\
\text { deaths }\end{array}$ & ed $S M K$ & २ 95\% CI & $\begin{array}{l}\text { Observec } \\
\text { deaths }\end{array}$ & ed $S M R$ & २ 95\% CI \\
\hline All causes & 1046 & 67 & 63 to 71 & 1379 & 77 & 73 to 81 & 684 & 76 & 70 to 81 & 1260 & 76 & 72 to 80 & 711 & 72 & 67 to 78 \\
\hline All cancers $(140-209)$ & 293 & 80 & 71 to 90 & 322 & 84 & 75 to 93 & 173 & 86 & 74 to 100 & 310 & 84 & 75 to 94 & 175 & 84 & 72 to 98 \\
\hline Digestive system (150-159) & 73 & 78 & 61 to 98 & 67 & 64 & 49 to 81 & 30 & 56 & 38 to 80 & 61 & 62 & 48 to 80 & 38 & 67 & 47 to 92 \\
\hline Stomach (151) & 13 & 91 & 48 to 155 & 9 & 50 & 23 to 96 & 3 & 34 & 7 to 101 & 7 & 44 & 18 to 91 & 5 & 52 & 17 to 122 \\
\hline Large intestine (153) & 29 & 84 & 56 to 121 & 22 & 58 & 37 to 88 & 13 & 67 & 35 to 114 & 22 & 62 & 39 to & 20 & 97 & 59 to 150 \\
\hline Liver $(155-156)$ & 7 & 110 & 44 to 226 & 10 & 136 & 65 to 250 & 1 & 27 & 0 to 150 & 9 & 133 & 61 to 252 & 0 & 0 & 0 to 92 \\
\hline Pancreas (157) & 15 & 82 & 46 to 135 & 19 & 95 & 57 to 149 & 6 & 58 & 21 to 127 & 17 & 90 & 53 to 145 & 8 & 74 & 32 to 146 \\
\hline Lung (162) & 85 & 67 & 54 to 83 & 109 & 88 & 73 to 107 & 55 & 83 & 62 to 108 & 118 & 96 & 80 to 115 & 50 & 76 & 57 to 101 \\
\hline Skin $(172-17$ & 6 & 85 & 31 to 185 & 5 & 78 & 25 to 182 & 0 & & & 3 & 45 & 9 to 132 & 4 & 127 & 34 to 324 \\
\hline Prosta & 34 & 111 & 77 to 155 & 46 & 122 & 89 to 162 & 29 & 154 & 103 to 221 & 38 & 114 & 81 to 156 & 28 & 130 & 86 to 188 \\
\hline Bladder (188) & 10 & 97 & 47 to 179 & 12 & 95 & 49 to 165 & 5 & 79 & 25 to 184 & 9 & 80 & 36 to 152 & 5 & 70 & 22 to 163 \\
\hline Kidney (189) & 5 & 56 & 18 to 130 & 5 & 55 & 18 to 129 & 6 & 125 & 46 to 273 & 4 & 45 & 12 to 116 & 1 & 21 & 0 to 116 \\
\hline $\begin{array}{l}\text { Brain and CNS (191-192) } \\
\text { Lymphatic and }\end{array}$ & 17 & 183 & 107 to 293 & 9 & 107 & 49 to 203 & 3 & 65 & 13 to 190 & 6 & 67 & 24 to 146 & 4 & 92 & 25 to 234 \\
\hline $\begin{array}{l}\text { haematopoietic (200-209) } \\
\text { Lymphosarcoma and }\end{array}$ & 38 & 112 & 79 to 154 & 27 & 77 & 51 to 112 & 24 & 130 & 84 to 194 & 33 & 96 & 66 to 135 & 25 & 131 & 85 to 194 \\
\hline reticulosarcoma (200) & 2 & 44 & 5 to 159 & 1 & 19 & 0 to 106 & 2 & 75 & 8 to 270 & 2 & 40 & & 2 & 68 & 8 to 246 \\
\hline Hodgkin's disease (201) & 2 & 88 & 10 to 318 & 1 & 43 & 1 to 239 & 1 & 83 & 1 to 462 & 2 & 80 & 9 to 290 & 2 & 155 & 17 to 561 \\
\hline Leukaemia (204-207) & 12 & 90 & 46 to 156 & 13 & 90 & 48 to 154 & 11 & 147 & 73 to 263 & 17 & 123 & 71 to 196 & 10 & 127 & 61 to 233 \\
\hline $\begin{array}{l}\text { Other lymphatic tissue } \\
(202,203,208)\end{array}$ & & & & & & & & & & & & & & & \\
\hline & 20 & 156 & & 11 & 91 & & 9 & 137 & & 12 & 99 & & 9 & 140 & 64 to 265 \\
\hline Benign neoplasms (210 to 239 ) & 5 & 133 & 43 to 309 & 5 & 122 & 39 to 284 & 6 & 280 & 102 to 610 & 3 & 75 & 15 to 218 & 6 & 259 & 95 to 564 \\
\hline
\end{tabular}

p-y $=$ Person years.

from acute lymphocytic leukaemia was the same as expected (SMR 104), and there was a deficit for chronic lymphocytic leukaemia (SMR 52). Mortality from chronic myelogenous leukaemia was essentially the same as expected (SMR 94). For acute leukaemia and for unspecified leukaemia, mortality was nonsignificantly increased (SMRs 150 and 175, respectively).

However, there was a significant excess of deaths from acute myelogenous leukaemia (SMR 192) which was based on 16 deaths. The increase was restricted to those who were first employed before 1940 (SMR 374), and who were employed in production and pipeline jobs for at least 20 years (SMR 265). An examination of the work histories for these workers showed that most were employed as roustabouts (SMR 276), pumpers (all were also employed as roustabouts, SMR 280), or pipeline field personnel (SMR 247). These were the most common jobs for most of this cohort.

Table 6 Study of crude oil workers: SMRs for lymphohaematopoietic cancer, white men, 1946-94

\begin{tabular}{lrrrl}
\hline & Observed & Expected & SMR & 95\% CI \\
\hline Non-Hodgkin's lymphoma & \multicolumn{1}{c}{ S2 } & 45.9 & 69 & 47 to 98 \\
Multiple myeloma & 23 & 18.7 & 122 & 77 to 184 \\
Leukaemia & 49 & 50.3 & 97 & 72 to 129 \\
Acute lymphocytic leukaemia (ALL) & 3 & 2.9 & 104 & 20 to 305 \\
Chronic lymphocytic leukaemia (CLL) & 5 & 9.6 & 52 & 16 to 121 \\
Acute myelogenous leukaemia (AML) & 16 & 8.3 & 192 & 110 to 313 \\
Ever employed as roustabout & 12 & 4.3 & 276 & 142 to 482 \\
Ever employed as pumper & 9 & 3.2 & 280 & 127 to 531 \\
Ever employed in maintenance & 4 & 2.7 & 148 & 39 to 380 \\
Ever employed in pipeline field & 4 & 1.6 & 247 & 66 to 632 \\
First employed <1940 & 11 & 2.9 & 374 & 186 to 670 \\
First employed 1940 to 9 & 2 & 2.6 & 77 & 8 to 280 \\
First employed $\geqslant 1950$ & 3 & 2.9 & 105 & 21 to 307 \\
Employed <20 y & 3 & 3.4 & 88 & 17 to 257 \\
Employed $\geqslant 20$ y & 13 & 4.9 & 265 & 141 to 453 \\
Chronic myelogenous leukaemia (CML) & 6 & 6.3 & 94 & 34 to 205 \\
Acute unspecified leukaemia (AUL) & 4 & 2.7 & 150 & 40 to 384 \\
Unspecified leukaemia (UL) & 6 & 3.4 & 175 & 64 to 382 \\
\hline
\end{tabular}

\section{Discussion}

The patterns of mortality found in this updated study of workers engaged in the production of crude oil were similar to those found in the first analysis of this cohort. ${ }^{1}$ There was a more favourable mortality experience for the cohort compared with the United States population, and there were deficits for all of the leading causes of death in the United States including all cancers, heart disease, stroke, lung cancer, respiratory disease, and external causes of death. The only increased causes of death found in the general analysis of the cohort of white men were for thyroid cancer and for benign and unspecified neoplasms; these increases were not significant. The increase in thyroid cancer was found in the earlier analysis of this cohort, ${ }^{1}$ based on only four deaths. No additional deaths from thyroid cancer have occurred since 1980, and the SMR has decreased from 342 to 175 . Over half of the deaths from benign and unspecified neoplasms were from benign and unspecified tumours of the brain. When these brain tumours were examined together with the brain cancers, the overall brain tumour SMR was only slightly increased. There was a significantly increased SMR for cancer of the brain and CNS but only for the unexposed group and this might be due to more complete diagnosis in this group.

The results of this analysis are consistent with those found in other studies of petroleum industry workers. In general, these studies have all shown a strong healthy worker effect with numerous significant deficits for most leading causes of death and few significant increases. The study results are also consistent with the conclusions of a meta-analysis of specific cancers in workers employed in various segments of the petroleum industry. ${ }^{4}$ Wong and Rabe found that petroleum industry 
workers had a significantly low cancer mortality for all cancer sites combined and for cancers of the digestive system, stomach, and lung. Similar deficits were found in this study. They also found mortality to be similar to that for the United States population for cancers of the skin, brain, pancreas, prostate, and kidney. Small increases for these causes occurred among various subgroups in this study, but the increases were not consistent nor were they linked with increasing duration of employment in the job subgroups.

The slight excess of brain tumours is not uncommon in studies in the petroleum industry. A similar small increase in brain tumours has been reported by Divine and Hartman ${ }^{3}$ in a large study of refinery, petrochemical, and research workers and by Satin et $a \bar{P}$ in a large cohort refinery study. Satin et al also noted that the brain is often a metastatic cancer site. A previous report on brain tumours in this same refinery cohor $\mathrm{t}^{6}$ discussed the problems associated with diagnostic errors of brain tumours that may lead to increases in employed populations.

The meta-analysis of studies of petroleum industry workers by Wong and Raabe ${ }^{4}$ suggested that some petroleum workers, especially those first employed before 1940, might have an increased risk of leukaemia. A subsequent meta-analysis of leukaemia cell type specific results in petroleum industry cohorts $^{7}$ did not show increased SMRs for acute myelogenous leukaemia or any of the other leukaemia cell types. However, a casecontrol study of leukaemia among petroleum workers at the Unocal Corporation ${ }^{8}$ found myelogenous leukaemia to be associated with work related to production in the oil and gas division of the company (odds ratio (OR) 2.0). The association was even stronger for those employed for $>30$ years in activities related to production (OR 3.9) and also for those with acute myelogenous leukaemia (OR 2.8). The researchers also found a consistent trend of increasing ORs with increasing duration of employment.

The analysis of leukaemia by cell type for the present cohort showed an increased SMR for acute myelogenous leukaemia among white men which was restricted to those people first employed before 1940 with at least 30 years of employment in production and pipeline jobs. These results are, therefore, similar to those found in the Unocal study. No information was available to describe oil field exposures in the early 1900 s, but others have reported ${ }^{8}$ that personal hygiene was poor and that some oil field workers had heavy exposure to crude oil. In particular, there is no information about the benzene content of the crude oil over time or oil fields. Furthermore, it is not known whether benzene was used as a solvent or cleaning agent in oil field work in the past. Increased risk of leukaemia (for all cell types except chronic lymphocytic leukaemia) has also been associated with exposure to large doses of ionising radiation. Although there is potential for exposure to naturally occurring radioactive material in the production fields, there is no consistent evidence that the low levels of natural background radiation increase the risk of leukaemia. ${ }^{9}$

This cohort study of crude oil production workers has many strengths. The cohort includes $>24000$ people whose mortality experience has been studied for 49 years (1946-94). Vital status is known for $>95 \%$ of the entire cohort, and for $>88 \%$ of the women. Only 89 of 4612 death certificates could not be found $(1.9 \%)$. Also, the study includes information about the cohort members' complete work histories, and numerous analyses by job were performed.

The study does have its limitations. As with other mortality studies, it has the problems inherent with using the death certificate diagnosis for the cause of deathfor example, diagnostic accuracy and specificity, and comparability of ICD codes over time. Mortalities vary over time and geographical location. Because this study covered many locations across the United States, the United States mortalities were used for comparison. Although the cohort was large, many of the analysis subgroups were small. Information about the specific chemicals associated with the jobs is not available, nor is there any industrial hygiene sampling data covering the first 35 years of the study. Jobs and units with similar responsibilities were grouped together for the analyses as a surrogate for exposures, but provide little information to link exposure and outcome.

\section{Conclusion}

The results of the update of workers engaged in the production of crude oil show a favourable mortality experience for these employees compared with the general United States population. Most causes of death in the study show either similar mortality or a significant deficit when compared with the general population. The overall $27 \%$ deficit in total deaths translates into an increased life expectancy of 3.7 years $^{10}$ for these workers compared with white men in the general population of the United States. The few increases in various causes of death were not consistently found across jobs with similar exposures, nor did most rise with increasing duration of employment.

There was an apparent excess of death for some of the leukaemia cell type specific causes of death, including acute myelogenous leukaemia. The increased mortality from acute myelogenous leukaemia was found only in those people who were first employed before 1940 and who were employed in the production of crude oil for $>30$ years.

1 Divine BJ, Barron V. Texaco mortality study III. A cohort study of producing and pipeline workers. Am F Ind Med study of producin

2 Monson RR. Analysis of relative survival and proportionate mortality. Computer Biomed Res 1974;7:325-32. 
3 Divine BJ, Hartman CM, Wendt JK. An update of the Texaco mortality study 1947-1993: part II. Analysis of specific causes of death for white males employed in refining, research, and petrochemicals. Occup Environ Med 1999;56:174-80.

4 Wong O, Raabe GK. Critical review of cancer epidemiology in petroleum industry employees, with a quantitative metaanalysis by cancer site. Am f Ind Med 1989;15:283-310.

5 Satin KP, Wong O, Yuan LA, et al. A 50 year mortality follow up of a large cohort of oil refinery workers in Texas. $\mathcal{F}$ Occup Environ Med 1996;38:492-506.

6 Wen CP, Tsai SP, Gibson RL. A report on brain tumors from a retrospective cohort study of refinery workers. Ann NY Acad Sci 1981;381:130-8.
7 Wong O, Raabe GK. Cell-type specific leukemia analyses in a combined cohort of more than 208000 petroleum workers in the United States and the United Kingdom. Reg Toxicol Pharmacol 1995;21:307-21.

8 Sathiakumar N, Delzell E, Cole P, et al. A case-control study of leukemia among petroleum workers. f Occup Environ Med 1995;37:1269-77.

9 Linet MS, Cartwright RA. The leukemias. In: Schottenfeld D, Fraumeni JF Jr, eds. Cancer epidemiology and prevention. New York: Oxford University Press, 1996:841-92.

10 Tsai SP, Hardy RJ, Wen CP. The standardized mortality ratio and life expectancy. Am f Epidemiol 1992;135: 824-31

\section{Vancouver style}

All manuscripts submitted to Occup Environ Med should conform to the uniform requirements for manuscripts submitted to biomedical journals (known as the Vancouver style.)

Occup Environ Med, together with many other international biomedical journals, has agreed to accept articles prepared in accordance with the Vancouver style. The style (described in full in the $\mathcal{F} A M A[1]$ ) is intended to standardise requirements for authors, and is the same as in this issue.

References should be numbered consecutively in the order in which they are first mentioned in the text by Arabic numerals on the line in square brackets on each occasion the reference is cited (Manson[1] confirmed other reports[2][3][4][5]). In future references to papers submitted to Occup Environ Med should include: the names of all authors if there are three or less or, if there are more, the first three followed by et al; the title of journal articles or book chapters; the titles of journals abbreviated according to the style of Index Medicus; and the first and final page numbers of the article or chapter. Titles not in Index Medicus should be given in full.

Examples of common forms of references are:

1 International Committee of Medical Journal Editors. Uniform requirements for manuscripts submitted to biomed journals. FAMA 1993;269:2282-6.

2 Soter NA, Wasserman SI, Austen KF. Cold urticaria: release into the circulation of histmaine and eosinophil chemotactic factor of anaphylaxis during cold challenge. N Engl F Med 1976;294:687-90.

3 Weinstein L, Swartz MN. Pathogenic properties of invading micro-organisms. In: Sodeman WA Jr, Sodeman WA, eds. Pathologic physiology, mechanisms of disease. Philadelphia: W B Saunders, 1974:457-72. 